\title{
LABA: KETIDAKSTABILAN MAKNA
}

\author{
Sulis Rochayatun ${ }^{1}$ \\ Email: sulis@uin-malang.ac.id \\ Fitriya Andriyani² \\ Email: fitryandry10@gmail.com
}

\begin{abstract}
The purpose of this study is to find out how accountants and nonaccountants interpret earnings, and what the reality behind the interpretation. Reality in the accounting profession and students of SMK Akuntansi establish a perception that profit is matching between income and expense (syntactic). Profit is a form of cash proceeds, an increase in economic capability, and a representation of company performance (semantics). Profit is also considered an indicator of corporate success and a tool for controlling management (pragmatics).

The results of this study indicate that profit has the meaning of denotation and connotation. Profit not only contains elements of materialism, not only as a form of capitalism, naum profit also contains elements of humanism. The reality of accountants results in the perception that profit is the matching between income and expense. In contrast to these conditions, the reality of nonaccountant actually shows more aspects of humanism. These perceptions all have their own truths. This is because the reality that the informants refer to is also different. Thus we know that the meaning of the profit "text" is unstable.
\end{abstract}

Keywords: Earnings, Profit, Unstable, Perception

\section{PENDAHULUAN}

Akuntansi dapat dipandang sebagai suatu bahasa, karena terdapat karakteristik leksikal dan gramatikal suatu bahasa yang melekat dalam akuntansi (Belkoui, 1980: 363). Kedua karakteristik tersebut merupakan komponen dari sebuah bahasa. Hal ini diperkuat oleh pernyataan Belkoui (1989: 282) yang mengemukakan bahwa "We identifies two components of a language, symbols or lexical characteristics and grammatical rules". Dengan simbol atau karakteristik tersebut dapat diartikan bahwa akuntansi memiliki unit-unit yang mengandung arti yang dapat diidentifikasi dalam setiap bahasa.

\footnotetext{
${ }^{1}$ Corresponding author: Univeritas Islam Negeri Maulana Malik Ibrahim Malang

${ }^{2}$ Universitas Negeri Malang
} 
Bahasa dalam akuntansi menggunakan istilah tanda, simbol ataupun dokumen seperti laporan laba rugi dan laporan posisi keuangan (Errol, 1971: 53). Salah satu tanda yang banyak diperbincangkan adalah laba (Macintosh et al, 2000: 38). Laba pada profesi yang berbeda memiliki makna yang berbeda, misalnya laba bagi dokter memiliki makna yang berbeda dengan laba bagi akuntan (Sari, 2010). Hal ini dikarenakan setiap individu memiliki perasaan, pengalaman, pengetahuan, ataupun latar belakang yang berbeda sehingga menghasilkan suatu persepsi yang berbeda.

Pernyataan tersebut didukung oleh Creswell (2009: 8) yang menyatakan bahwa persepsi ataupun interpretasi individu dibentuk oleh perasaan, pengalaman, dan kebudayaan yang melekat pada diri individu tersebut. Dengan demikian laba berpotensi memiliki makna majemuk atau memiliki ketidakstabilan makna.

Ketidakstabilan makna suatu teks diyakini kehadirannya oleh Rolland Barthes (1991: 131). Menurut Barthes (1991: 132), sebuah ungkapan atau karya bukanlah sebaris kata-kata yang menghasilkan makna tunggal teologis (pesan atau wahyu Tuhan), akan tetapi merupakan ruang multidimensional yang di dalamnya terdapat beraneka ragam tulisan yang saling berinteraksi. Interaksi yang terjadi tidak lagi bersifat simetris dan stabil, sehingga Barthes (1991: 131) mempercayai bahwa realitas itu tidak stabil.

Realitas yang diacu individu akan membentuk sebuah ide, dalam konteks ini ide tentang makna laba. Ide tersebut kemudian dituangkan dan dilekatkan pada teks "laba". Seperti sebuah apel, ide tentang apel hadir lebih dulu sebelum ada wujud buah apel. Orang bisa menyebut apel karena di dalam otaknya terdapat ide tentang apel. Ketika ia melihat sebuah buah kemudian ia melekatkan nama apel pada buah tersebut.

Begitu pula ide tentang laba, akuntan melekatkan teks "laba" pada kenaikan ekonomik perusahaan (Ridwan, 2010). Ini membuktikan bahwa laba dalam akuntansi modern hanya menggambarkan dan memperhitungkan biaya dalam unit moneter dan non moneter yang mungkin timbul akibat aktivitas bisnis perusahaan. Keberadaan laba menjadi sarat dengan nilai individualistik dan materialistik. Pernyataan ini diperkuat oleh Friedman yang menyatakan bahwa "There is one and only one social responsibility in business, to use its resources engage in activities designed to increase its profit."

Pada realitas yang berbeda makna laba tidak hanya semata-mata dinilai dari ukuran materi. Seorang dokter mengartikan laba ketika ia puas melihat pasiennya sembuh (Sari, 2010). Ini menunjukkan bahwa laba bisa dirasakan melalui batin. Realitas yang membentuk makna laba bagi seorang dokter tersebut telah mengandung unsur nilai-nilai kehidupan. Oleh karena realitas makna laba tidak stabil maka selain aspek pengukuran (sintaktik) dan kebermanfaatan (pragmatik), perlu juga menganalisis akuntansi dari realitas yang direpresentasikan (semantik).

Berdasarkan fenomena diatas, menjadi hal yang menarik bagi peneliti untuk melakukan penelitian mendalam tentang bagaimana profesi akuntan dan nonakuntan menginterpretasikan simbol laba? Kemudian realitas apa yang ada dibalik penafsiran akuntan dan non-akuntan terkait simbol laba tersebut? 


\section{LANDASAN TEORI}

\subsection{Semiotika Rolland Barthes}

Roland Barthes (1915-1980) adalah seorang tokoh utama dalam kajian bahasa sastra, budaya, dan media, baik sebagai penemu maupun pembimbing (Allen, 2003: 52). Barthes lahir di Cherbough, Manche, Prancis pada 1915 dan menghabiskan masa kecilnya di Bayonne, lalu pindah ke Paris. Barthes semakin dilihat sebagai tokoh terdepan dalam sebuah bentuk kritik sastra baru yang secara langsung diadu melawan macam kritik yang dipraktikkan di dalam universitasuniversitas besar, ada tahun 1960-an, (Allen, 2003: 53). Menurut Allen (2003: 53) karya-karya Barthes pada 1950-an dan 1960-an banyak menyulut debat antara bentuk-bentuk kritik yang konservatif dan avant- garde (perintis). Kemudian seiring dengan berjalannya waktu pada tahun 1970-an Barthes menunjukkan kecenderungan terhadap postrukturalisme, setelah sebelumnya mengarah kepada strukturalisme.

Pada awalnya Barthes merupakan pewaris Saussure yang merupakan pemikir semiotika struktural, pada perkembangan selanjutnya ia merupakan seorang yang cukup lantang menyatakan kritik terhadap semiotika struktural sendiri. Sebuah ungkapan atau karya, menurut Barthes (1991: 132) bukanlah sebaris kata-kata yang menghasilkan makna tunggal teologis (pesan atau wahyu Tuhan), akan tetapi ruang multidimensional yang di dalamnya terdapat beraneka ragam tulisan yang saling berinteraksi.

Barthes kemudian menuangkan pemikiran barunya di dalam "Mythology Today", yaitu sebuah pergantian mitos-mitos ke sebuah kritik radikal dan membongkar tanda itu sendiri. Perubahan fokus semacam ini membutuhkan macam semiologi yang baru dengan setelan kriteria yang berbeda (Allen, 2003: 65). Tugas semiologi yang baru ini adalah mengubah (menyerang) objek itu sendiri (Barthes dalam Allen, 2003: 65). Pemikiran Barthes dalam "Mythology Today" sangat dekat dengan filosofi dekonstruksi Derrida. Pusat sebuah teks tidak hanya berada di luar struktur yang distabilkannya, tapi maknanya juga bisa berada di tempat lain (Allen, 2003: 69).

Terdapat pula esai Barthes pada 1968 yang berjudul "The Death of the Author" yang merupakan esainya yang paling banyak dibaca (Allen, 2003: 73). Maksud kematian pengarang di sini adalah tulisan tidak bergantung kepada sebuah petanda penghabisan (yang dianggap berasal dari pengarang). Bagi Barthes, teks adalah ruang multidimensi yang dinikahi dan diperebutkan oleh

beberapa tulisan (tidak ada yang asli). Teks adalah pabrik kutipan, dihasilkan dari seribu sumber budaya (Barthes dalam Allen, 2003: 76).

\section{METODE PENELITIAN}

\subsection{Jenis dan Paradigma Penelitian}

Penelitian ini merupakan penelitian kualitatif atau lebih spesifik menggunakan paradigma postrukturalisme. Dengan demikian realitas bukanlah sesuatu yang objektif melainkan sesuatu yang bersifat subjektif karena makna dari suatu realitas sangat tergantung oleh manusia yang memahami realitas tersebut. Penelitian ini dilakukan dengan berpijak pada asumsi, pola pikir atau keyakinan , dengan berefleksi pada esensi dan karakteristik paradigma postrukturalisme seperti diuraikan oleh beberapa ahli, Adapun keyakinan-keyakinan yang mendasari adalah sebagai berikut. 
Pertama, keyakinan bahwa praktik akuntansi bukanlah sesuatu yang bersifat given melainkan diciptakan oleh pihak yang memiliki kuasa, yaitu akuntan. Sudut pandang akuntan akan berbeda dengan sudut pandang non akuntan dalam memaknai suatu realitas. Setiap individu akan memahami realitas melalui pemaknaan secara subjektif. Kedua, keyakinan akan teori dan praktik akuntansi erat dengan nilai, namun nilai tersebut tidak hanya akan ditangkap oleh indera. Nilai tersebut akan dipahami maknanya secara berbeda-beda oleh masing-masing individu. Interpretasi terhadap nilai tersebut adalah hal yang sangat penting untuk merepresentasikan realitas yang ada. Ketiga, keyakinan atas tindakan praktis yang dilakukan oleh individu (akuntan dan non-akuntan) didorong oleh kesadaran yang dimilikinya. Kesadaran tersebut terbentuk secara internal berdasarkan pengalaman. Pengalaman yang dimiliki setiap individu pasti akan berbeda sehingga cara mereka mendefinisikan realitas juga pasti akan berbeda. Keempat, keyakinan teori yang mendorong praktik akuntansi berjalan di atas kesadaran semu harus disikapi secara terbuka, dan dipandang perlu adanya pemikiran untuk memahami dan memaknai alasan dibalik suatu realitas.

\subsection{Sumber Data dan Metode Pengumpulan Data}

Sumber data dalam penelitian ini adalah dari hasil wawancara langsung kepada informan. Informan dalam penelitian ini adalah akuntan, siswa SMK Akuntansi, guru, dan pengusaha UMKM. Informan yang dipilih adalah mereka yang relevan untuk memberikan data dalam mencapai tujuan penelitian ini. Proporsi pemilihan informan non akuntan lebih besar dibandingkan informan akuntan.

Hal ini dilakukan untuk mendapatkan keberagaman makna laba (konotasi) dari sudut pandang yang berbeda, dari sudut pandang profesi non akuntansi. Dengan profesi, pengetahuan, pengalaman, perasaan, ataupun latar belakang yang berbeda, persepsi yang diberikan atas makna laba juga pasti sangat beragam. Masing-masing profesi tidak hanya mengambil satu informan, tetapi bisa beberapa informan. Informan akan diwawancarai hingga peneliti mendapatkan data jenuh. Jenuh dalam penelitian kualitatif bukan berarti mencari data pada setiap individu hingga mendapatkan interpretasi yang sama antara individu satu dengan yang lain, melainkan mencari data dari satu individu hingga pernyataan yang dia berikan berulang kembali, artinya tidak ada informasi baru yang disampaikan.

Keberagaman profesi yang dijadikan informan akan memberikan keberagaman makna laba dari sudut pandang yang berbeda. Selain itu dalam penelitian ini kita tidak berbicara keterwakilan, ataupun kesamaan persepsi dari profesi yang sama. Penelitian ini tidak ada generalisasi. Penelitian ini berhenti dengan cukup mendapatkan interpretasi dari apa yang diinterpretasikan informan. Tidak ada kriteria khusus seperti usia informan, lama bekerja, atau pengalaman kerja. Hal ini dikarenakan penelitian ini tidak membandingkan faktor-faktor tersebut. Penelitian ini justru lebih pada realitas yang ada dibalik penafsiran informan hingga pada batas perilaku subyek.

\subsection{Teknik Analisa Data}

Analisis data merupakan proses yang dilakukan setelah peneliti mengumpulkan data sesuai kondisi lapangan. Selanjutnya data hasil lapangan akan dirapikan ke dalam bentuk laporan lapangan. Orders of signification dari Rolland Barthes akan diterapkan dalam analisis data dan diskusi hasil. Orders of 
signification terdiri dari first order of signification yang artinya denotasi, sedangkan konotasi adalah second order of signification. Tatanan yang pertama mencakup penanda dan petanda yang berbentuk tanda. Tanda inilah yang disebut makna denotasi. Kemudian dari tanda tersebut muncul pemaknaan lain, sebuah konsep mental lain yang melekat pada tanda (penanda). Pemikiran baru inilah yang kemudian menjadi konotasi. Berdasarkan konsep tersebut maka tahap-tahap analisis dan diskusi dalam penelitian ini adalah sebagai berikut.

Pertama, pembacaan simbol laba dengan makna denotasi. Meskipun makna denotasi adalah makna yang sebenarnya, namun kenyataan bahwa realitas laba direpresentasikan secara berbeda berdasarkan pengalaman informan mungkin akan menghasilkan pemaknaan yang beragam pula terkait makna laba. Kedua, pembacaan simbol laba dengan makna konotasi. Pada tahap inilah dapat diketahui bagaimana akuntan dan non-akuntan menafsirkan makna laba dari realitas yang ada. Pada tahap analisis peneliti juga akan mengkaji tentang signifier dan signified hingga menghasilkan makna konotasi, atau mungkin bahkan mitos.

\section{HASIL PENELITIAN}

\subsection{Semiotika Laba dalam Makna Denotasi}

a. Semiotika Laba pada Tataran Sintaktik

Pada tataran sintaktik atau lebih jelasnya adalah secara struktur, konsep laba digambarkan dalam prosedur akuntansi sebagai hasil penandingan (matching) antara penghasilan dan beban. Konsep ini dirasionalkan dalam bentuk standar dan prosedur akuntansi yang objektif sehingga angka laba dapat diukur dan disajikan dalam laporan keuangan. Hasil penelitian menunjukkan bahwa konsep laba pada tataran sintaktik ini secara umum telah dipahami oleh para informan. Seperti yang disampaikan para informan berikut ini:

Para informan memahami laba akuntansi sebagai selisih antara penghasilan dan beban. Hal ini merupakan hasil dari realitas yang diacu oleh para informan. Ketika membaca atau mendengar kata "laba", ide-ide dalam kognisi informan yang terkait dengan "laba" teraktivasi secara otomatis melekatkan penghasilan dan beban sebagai aspek dalam perhitungan laba.

\section{b. Semiotika Laba pada Tataran Semantik}

Realitas terkait pemaknaan angka laba akuntansi sebagai hasil usaha tunai diberikan oleh Aini (Siswa SMK Akuntansi). Bagi Aini laba adalah hasil usaha bersih yang dapat secara langsung dinikmati atau digunakan. Pemahaman informan tentang laba tersebut sangat terkait dengan aktivitas sehari-harinya. Aini tidak hanya belajar tentang akuntansi tetapi dia juga bekerja di sebuah home industry dengan tujuan utama untuk memperoleh pendapatan riil berupa uang dari hasil kerjanya. Aini mengatakan bahwa:

"Meskipun upah saya minim karena saya hanya bekerja paruh waktu, tapi saya merasa hasil kerja saya merupakan laba buat saya, karena uang tersebut bisa langsung saya gunakan untuk uang saku sekolah, dan untuk keperluan yang lain."

Selain itu laba dianggap sebagai kenaikan kemampuan ekonomik. Mima (Siswa Akuntansi) memahami bahwa laba akuntansi tidak selalu riil berwujud uang tunai. Oleh karena itu, ia menafsirkan laba akuntansi sebagai tambahan kemampuan 
ekonomik perusahaan yang wujudnya bisa bermacam-macam. Berikut pernyataan Mima:

"Laba kan gak selalu dilihat dalam bentuk uang. Kalau saya melihat ditempat saya bekerja ini, laba bisa berwujud bangunan juga. Faktanya ada bangunan baru untuk memperluas tempat produksi ini. Itu juga laba menurut saya."

Dari sini kita melihat bahwa akuntansi menganut asas akrual untuk mendapatkan suatu angka yang lebih bermakna secara ekonomik daripada sekedar kenaikan atau penurunan kas dalam suatu periode. Laba disini tidak berupa kenaikan satuan uang melainkan berupa kenaikan kemampuan ekonomik.

Laba juga dianggap sebagai pengukur kinerja perusahaan. Agus (akuntan publik) menafsirkan laba akuntansi sebagai representasi dari kinerja perusahaan, karena laba menentukan ROI, ROA, dan ROL sebagai pengukur efisiensi. Agus mempertegas hal ini dengan menyatakan bahwa:

\section{"Laba dapat diinterpretasikan sebagai pengukur keefisienan kinerja perusahaan bila dihubungkan dengan tingkat investasi karena efisien secara konseptual merupakan suatu hubungan atau indeks."}

Dengan demikian kemampuan perusahaan dalam menghasilkan laba merupakan informasi yang diharapkan oleh para stakeholder. Penyusun laporan keuangan (perusahaan) berusaha menyediakan informasi untuk meyakinkan bahwa harapan-harapan para pemakai laporan keuangan dimasa lalu tentang kinerja perusahaan memang terealisasi.

Dari penjelasan para informan tergambar jelas bahwa makna laba sangat erat dengan nilai materi, baik itu yang berupa uang tunai, kenaikan kemampuan ekonomi, serta tolak ukur kinerja perusahaan. Dalam PSAK No. 1 (2009), tercermin sifat materialistik, dan individualistik yang terkandung dalam konsep laba akuntansi. Materialisme merupakan bagian dari filsafat metafisika yang mengarahkan dirinya kepada anggapan bahwa kenyataan yang sesungguhnya adalah benda atau materi (Subiyantoro dan Triyuwono, 2004:180). Dalam praktik dunia ekonomi, salah satu wujud materi yang jelas nampak sebagai wujud materialisme ialah uang. Uang merupakan salah satu unsur pendukung penting dalam skema pasar kapitalis.

Akuntansi sebagai salah satu cabang ilmu ekonomi yang secara khusus berbicara mengenai ekonomi mikro, yang melibatkan perusahaan-perusahaan dalam melaporkan aktivitas keuangannya, bagi banyak orang dianggap sarat dengan cerminan nilai-nilai materialistik. Nilai materialistik tersebut tercermin dari penyelenggaraan akuntansi pada umumnya dan konsep laba pada khususnya, yang sampai hari ini masih menggunakan dasar anggapan satuan moneter sebagai satuan ukur untuk semua kegiatan ekonomi yang dilakukannya. Hal ini dikarenakan adanya kesulitan bagi banyak pelaku bisnis, seperti pemilik (investor), manajer, akuntan dan para pengguna laporan keuangan lainnya, untuk melaporkan penghitungan kinerja perusahaan pada satuan non-moneter, sehingga menjadi tidak salah jika dalam penyelenggaraannya hingga saat ini, konsep laba pada khususnya dan akuntansi pada umumnya menjadi terbatas pada ruang penilaian yang materialistik. Akibat yang terjadi dari pembatasan akuntansi pada ruang penilaian 
materialistik tersebut, menurut Triyuwono (2006: 375-376) ialah:

\begin{abstract}
"Dengan sifat materialistik ini secara otomatis akuntansi modern menyajikan informasi akuntansi yang sifatnya materialistik. Informasi yang demikian, untuk selanjutnya, akan mempengaruhi keputusan ekonomi yang dilakukan seseorang yang telah mengonsumsi informasi yang materialistik. Akibat selanjutnya adalah terciptanya realitas yang materialistik. Realitas yang materialistik ini bukan sekedar ilusi, tetapi adalah fakta empiris yang dapat kita temukan dalam kehidupan seharihari, yaitu kehidupan manusia modern. Manusia modern berorientasi pada dunia materi, dan sebaliknya, mengabaikan dunia non-materi. Seluruh jaring kehidupan manusia modern mengarah dan terperangkap ke dalam jaring-jaring kehidupan materi..."
\end{abstract}

Dengan demikian menjadi tidak salah jika dalam praktiknya hari ini, penggunaan konsep satuan moneter sebagai basis utama dalam mengukur nilai keberhasilan dari suatu unit usaha menjadi titik penting dalam menilai keberhasilan suatu entitas. Akibatnya manusia modern hasil bentukkan realitas tersebut menjadi sarat dengan nilai materialistik.

Selain sarat dengan nilai materialistik, manusia modern didorong oleh suatu keinginan untuk memajukan kehidupannya sendiri untuk menjadi lebih baik dibandingkan masa-masa sebelumnya. Dengan demikian dalam memaknai motif atau dorongan terdalam dari pasar kapitalis, ia dapat diartikan sebagai sebuah konsep tujuan untuk pemenuhan kepentingan diri sendiri. Hal ini dipertegas oleh Astri (Siswa Akuntansi):

"saya kerja paruh waktu untuk cari uang saku tambahan. Selain itu saya menjadi reseller, jadi produk yang saya beli disini saya jual kembali, biar ada uang tambahan gitu."

Bagi Smith, self-interest merupakan motivasi utama yang mendorong para pelaku ekonomi untuk mengadakan kegiatan ekonomis. Para pelaku ekonomi melakukan transaksi perdagangan demi kepentingan diri mereka masing-masing. Tanpa self-interest perdagangan tidak akan pernah terjadi. Maka self-intetrest, menurut Smith menjadi titik tolak dorongan dari kegiatan jual beli di pasar.

Dengan menggunakan dasar pandangan ini, Smith menolak pandangan yang menegaskan kebaikan hati yang merupakan cerminan sikap etis dari bisnis, karena baginya dalam bidang ekonomi hal tersebut kurang memiliki relevansi. Smith menyatakan bahwa sikap etis dalam konteks ekonomi hanya akan tercermin dalam hubungan timbal balik antar para pelaku pasar yang memperlihatkan

dirinya dengan perlakuan yang saling menguntungkan satu sama lain. Keadilan dalam konteks lebih luas yang berkenaan dengan anggota masyarakat akan terjadi secara otomatis tanpa dipikirkan oleh pelaku bisnis, karena inti dari bisnis bagi Smith ialah memperkerjakan seluruh elemen di dalam suatu masyarakat.

Gambaran kritis terhadap peletakan dasar kepentingan diri sendiri sebagai bentuk penciptaan keadilan menurut Smith tersebut, kemudian digambarkan Marx dengan pendapatnya mengenai teori nilai lebih. Dalam teori nilai lebih Marx memperlihatkan bahwa seluruh keuntungan yang dicapai oleh para pelaku ekonomi 
tidaklah lebih dari pada hasil kerja buruh yang tidak dibayarkan kepadanya. Menurut Marx dalam Suseno (1999:180), seluruh modal yang terkumpul dalam tangan para kapitalis merupakan hasil curian dan sebetulnya milik buruh.

Analisis Marx tersebut berangkat dari suatu posisi bahwa ilmu ekonomi memiliki tujuan untuk menemukan dan menjelaskan secara cermat mengenai logika yang mendasari realitas ekonomi yang mengontrol tindakan manusia. Dengan demikian teori nilai lebih muncul untuk memperlihatkan ketidakadilan dari sistem kapitalisme yang digagas Smith.

\section{c. Semiotika Laba pada Tataran Pragmatik}

Tataran pragmatik membahas apakah informasi laba bermanfaat dan atau apakah informasi laba nyata digunakan. Adanya reaksi para informan menjadi bukti nyata kebermanfaatan informasi laba akuntansi. Persepsi informan tentang kebermanfaatan informasi laba pada tataran pragmatik ini dilandasi oleh penafsiran informan atas laba akuntansi pada tataran sintaktik maupun semantik. Berdasarkan realitas yang diacu masing-masing informan, kebermanfaatan informasi laba akuntansi adalah: (a) indikator keberhasilan perusahaan, (b) pengendalian manajemen.

Laba akuntansi dapat dijadikan sebagai alat ukur keberhasilan perusahaan. Meskipun demikian informasi selain laba akuntansi juga tetap memiliki kebermanfaatan bagi investor atau stakeholder lainnya dalam menilai keberhasilan perusahaan. Hal ini dipertegas oleh Arsanto (akuntan publik):

"laba yang tinggi kan tidak selalu berarti perusahaannya berhasil, karena sekarang banyak sekali kegiatan memanipulasi laba. maka dari itu meskipun laba bisa dijadikan indikator keberhasilan perusahaan, tetapi kita juga harus melihat informasi lain, yang sebenarnya juga memiliki manfaat yang bisa jadi lebih penting daripada informasi tentang laba."

Dari pernyataan Arsanto tampak adanya keraguan bahwa angka "laba" tidak selalu merefleksikan keadaan yang sebenarnya. Laba bisa sengaja dihadirkan hanya untuk pencitraan perusahaan (Baudrilard: 1980). Selain itu laba juga memiliki peran penting dalam suatu sistem pengendalian manajemen. Sistem pengendalian manajemen ini dirancang untuk mengerahkan perilaku para manajer agar mereka memaksimalkan kepentingan dirinya dan divisinya, namun pada saat yang sama kepentingan keseluruhan juga tercapai. Perilaku manajer dikendalikan melalui laba dengan cara mengaitkan kompensasi dengan laba sebagai pengukur kinerja. Berikut pernyataan Agus (akuntan publik) terkait kebermanfaatan laba sebagai pengendalian manajemen:

"kalau berbicara soal laba, saya tertarik untuk mengaitkannya dengan manajemen dan sistem bonus. Manajemen akan berusaha semaksimal mungkin untuk mencetak laba sesuai harapan pemilik, tapi tentu saja manajemen mengharapkan imbalan, biasanya berupa bonus. Tapi ya ini simbiosis mutualisme lah ya. Manajemen kan akhirnya bisa dikendalikan." 
Dalam kajian laba menggunakan teori semiotika menghasilkan fakta yang tergambar secara jelas, bahwa dalam praktiknya, penafsiran atas "laba akuntansi" belum bermuara pada realitas yang sama, kecuali pada tataran sintakik (perhitungan laba). Realitas masing-masing individu memang berbeda. Fakta empiris ini konsisten dengan pernyataan Azra $(2005,151)$, bahwa "pandangan dunia" setiap orang selalu berbeda-beda, bergantung pada lingkungan sosial, pendidikan dan kulturalnya. Oleh karena itu, akuntan memiliki pemahaman dan penafsiran yang berbeda-beda atas laba akuntansi, karena pandangan dunia mereka dibentuk oleh realitas yang tidak sama. Dikatakan pula oleh Fiske (2006, 63), bahwa:

Sebuah tanda mengacu pada sesuatu di luar dirinya sendiri, yaitu objek. Dalam setiap konteks, tanda akan menghasilkan pengalaman pengguna atas objeknya. Jadi, makna itu tidak tetap, dirumuskan kamus, namun bisa beragam dalam batas-batas sesuai dengan pengalaman penggunanya. Batasan itu ditetapkan oleh konvensi sosial; namun variasi di dalamnya memungkinkan adanya perbedaan sosial dan psikologis di antara penggunanya.

Pernyataan Fiske tersebut konsisten dengan fakta atas penafsiran laba akuntansi. Teks "laba akuntansi", ketika dihampiri dengan "pre-teks" yang beraneka ragam, terbukti memunculkan penafsiran beragam pula. Secara tekstual, laba akuntansi sebagai bottom line, adalah satu; tetapi ketika akal sudah mulai tergerak untuk memahami dan memanfaatkannya di dunia praktik, variasi dan ambivalensi pemahaman terjadi di antara pembaca atau penggunanya, sehingga pluralitas dan ambivalensi penafsiran ini merupakan kenyataan yang tidak dapat dielakkan.

\subsection{Semiotika Laba sebagai Keberkahan}

Konsep laba dalam akuntansi modern meliputi bentuk nilai materi dan nonmateri. Bentuk nilai materi dari konsep laba ini, dapat terlihat dari konsep penghitungan laba-rugi akuntansi konvensional yang sebatas menggambarkan penghitungan selisih total pendapatan dikurangi beban, yang di dalamnya tidak termasuk komponen-komponen pendapatan komprehensif lainnya (PSAK No.1 tahun 2009). Konsep tersebut tercermin dalam bentuk satuan terukur (materi) yang bersifat tangible, yaitu uang. Sedangkan bentuk nilai non-materi, dapat terlihat dari konsep penghitungan laba-rugi yang tidak hanya memperhitungkan selisih total pendapatan dikurangi beban dalam bingkai materi, namun juga merupakan sebuah konsep yang memperhatikan aspek-aspek nilai dalam satuan tidak terukur (nonmateri) yang bersifat intangible, seperti kepuasan batin (mental) dan keikhlasan, serta rasa kehadiran Tuhan yang selalu timbul ketika manusia tersebut melakukan kegiatan usahanya (spiritual). Sehingga dalam memahami laba dalam bingkai ini, ia merupakan suatu bentuk physical income, yang memiliki orientasi besar pada nilai dari tingkat kesenangan terhadap segala aspek pemenuhan kebutuhan hidupnya.

Dalam memahami laba dalam bingkai non-materi, setidaknya terdapat dua kata kunci untuk memahaminya, yaitu mental dan spiritual. Mental sebagai bagian dari bentuk nilai non-materi dari konsep laba dapat diartikan sebagai sebuah reaksi terhadap nilai atau jumlah dari pencapaian tertentu yang memiliki implikasi kepada orang tertentu ketika ia mendapatkannya. Mental berkembang seiring waktu untuk 
membantu manusia memecahkan masalah. Mental berguna karena ia memotivasi manusia untuk terlibat dalam beragam tindakan penting dalam pengambilan keputusan.

Salah satu cara mengklasifikasi mental adalah mengukurnya dalam bentuk nilai dari reaksi positif dan negatif. Mental positif dapat tercermin dari perasaan gembira, sedangkan mental negatif dapat tercermin dari perasaan marah ataupun kecewa. Dalam memahami laba non-materi yang termanifestasi dalam bentuk mental, pemahaman akan bentuk reaksi yang berhubungan dengan kemampuan seseorang untuk menerima, menilai dan mengelola perasaan terhadap dirinya sendiri maupun orang lain dapat dijadikan sebuah landasan dalam melihat manifestasi dari konsep laba ini secara lebih luas dan mendalam. Karena dalam membahas mental disini, kita tidak hanya berbicara mengenai kepentingan dan perasaan diri kita semata, namun kita juga berbicara mengenai kepentingan serta perasaan pihak-pihak yang terkait dalam proses mendapatkan laba. Kemampuan kita untuk memahami dan merasakan apa yang dirasakan orang lain dapat digunakan sebagai kunci untuk memahami laba dalam kajian non-materi ini.

Laba sebagai perwujudan nilai mental ini dapat dirasakan dalam bentuk kepuasan batin yang tercermin dalam proses mendapatkan laba tersebut. Kemudian spiritual sebagai kata kunci dalam memahami laba non-materi menurut asal katanya berasal dari bahasa Latin spiritus yang dapat diterjemahkan sebagai sesuatu yang memberikan kehidupan atau vitalitas pada sebuah sistem. Spiritual berangkat dan berdasar dari nilai-nilai ajaran agama, namun ia hendaknya jangan dimaknai sebatas ajaran agama-agama tertentu meskipun keduanya berhubungan. Spiritual merupakan suatu bentuk nilai universal dari setiap agama yang memiliki makna mengenai nilai ketuhanan yang lebih besar dan luas.

Makna laba yang sangat erat dengan nilai ketuhanan didapat dari dua orang pendidik generasi penerus bangsa. Guru yang satu ini memiliki kepribadian yang menawan, ramah dan sabar. Profilenya sebagai guru dengan pembawaan yang polos dan tampak sederhana, terlihat dari gaya bicaranya yang lemah lembut. sikap tulus dan perhatian pada semua orang di sekitarnya, baik itu rekan kerja atau siswa yang diajarnya, menunjukkan kepribadiannya yang mengagumkan. Sebagai seorang guru di sebuah Sekolah Menengah Atas, Bu Nurul memiliki pemahaman tersendiri yang unik mengenai laba. Selain sebagai guru, beliau memiliki usaha bakso, namun baginya laba adalah sesuatu yang erat kaitannya dengan nurani. Berikut ini penuturannya:

"Saya berbicara makna laba secara umum dulu. Umumnya laba itu kan keuntungan atau bahasa Jawa-nya "Bathi". Tapi kalau saya menilai, laba/ keuntungan/ bathi ini tidak $100 \%$ dinilai secara nominal. Saya bekerja di sekolah ini, kemudian saya mengajar, lalu siswa yang saya ajar menjadi pintar, lalu mereka mengajarkan ilmu itu pada orang lain. Nah itu adalah untung buat saya, katakanlah laba saya. Barokah ilmunya akan sampai juga pada saya."

Dari pernyataan tersebut diatas, tampak bahwa laba tidak dipandang dari bentuknya secara nominal, akan tetapi digambarkan sebagai sesuatu yang bisa dirasakan melalui nurani. Makna laba ditangkap melalui bentuknya yang abstrak dan hanya dapat dilihat melalui hati nurani seseorang. 
Laba yang dirasakan $\mathrm{Bu}$ Nurul adalah perasaan bahagia yang dialaminya saat mengajar, berbagi ilmu dengan penuh suka cita, kemudian merasakan ilmu tersebut bermanfaat bagi siswanya. Hal tersebut merupakan bentuk nyata dari laba yang diperolehnya. Dalam konteks ini, laba terlepas dari bentuknya secara materi dan menjelma melalui wujudnya yang abstrak, kemudian membentuk sebuah keberkahan. Bu Nurul juga menambahkan penjelasan yang telah dikemukakan sebelumnya, yaitu:

"Kalau soal uang, banyak sedikit itu akan terasa selalu cukup kalau disyukuri, namanya rezeki ya harus selalu disyukuri, sudah diatur oleh Allah, sehingga berapapun rezeki saya itu sudah sangat nikmat dan Alhamdulillah banget”.

Menurut Bu Nurul, berapa pun nilai dari materi yang diperoleh, telah diatur oleh Allah dan patut untuk disyukuri. Pada hakikatnya dengan mengucap syukur atas rejeki yang didapatkan maka kenikmatan dan kebahagiaan akan menjadi lebih terasa. Kebahagiaan batin direfleksikan dalam bentuk rasa syukur atas anugerah dari Allah yang tidak ternilai harganya. Dalam konteks ini, laba dilambangkan sebagai kebahagiaan batin yang tidak dapat dinilai dengan materi.

Kebahagiaan atau bahagia merupkan sebuah keadaan pikiran atau perasaan yang ditandai dengan cinta, kesenangan, kepuasan, kenikmatan. Pendefinisikan kebahagiaan dan menentukan sumbernya telah dilakukan dari berbagai pendekatan filsafat, agama, psikologi, dan biologi. Para filsuf dan pemikir agama sudah seringkali mendefinisikan kebahagiaan dalam kaitan dengan kehidupan yang baik dan tidak hanya sekadar sebagai suatu emosi. Meskipun pengukuran secara langsung atas derajat kebahagiaan masih menjadi sebuah tantangan, beberapa peneliti telah mengembangkan alat untuk melakukan hal itu, misalnya dengan The Oxford Happiness Questionnaire.

Pendangan bahwa puncak kebahagiaan pada manusia adalah jika dia berhasil mencapai ma'rifatullah, telah mengenal Allah SWT berasal dari pandangan Imam Al-Ghazali yang dikutip oleh Latief (2013), selanjutnya, Al-Ghazali menyatakan:

"Ketahuilah bahagia tiap-tiap sesuatu bila kita rasakan nikmat,
kesenangan dan kelezatannya maka rasa itu ialah menurut perasaan
masing-masing. Maka kelezatan (mata) ialah melihat rupa yang indah,
kenikmatan telinga mendengar suara yang merdu, demikian pula
segala anggota yang lain dan tubuh manusia."

Kelezatan hati adalah ma'rifat kepada Allah, karena hati dijadikan tidak lain untuk mengingat Tuhan. Seorang rakyat jelata akan sangat gembira jika dia dapat berkenalan dengan seorang pejabat tinggi atau menteri, dan kegembiraan itu akan menjadi naik berlipat ganda apabila dia dapat berkenalan yang lebih tinggi lagi misalnya presiden. Maka tentu saja berkenalan dengan Allah adalah puncak dari segala bentuk kegembiraan. Lebih dari apa yang dapat dibayangkan oleh manusia, sebab tidak ada yang lebih tinggi dari kemuliaan Allah. Dan oleh sebab itu tidak ada ma'rifat yang lebih lezat daripada ma'rifatullah (Latief 2013). 
Makna laba sebagai keberkahan diwujudkan sebagai bentuk rasa syukur atas karunia Tuhan. Hal ini tampak juga dari pernyataan yang disampaikan Bu Nurul sebelumnya, bahwa nilai nominal yang diperoleh dari tempatnya bekerja, patut untuk disyukuri. Hal ini dikarenakan semua yang diterima merupakan rezeki dari Allah. Mensyukuri setiap rezeki yang didapat sejatinya menimbulkan kenikmatan tersendiri bagi seseorang. Adpun pengertian syukur dan nikmat berasal dari bahasa Arab. Kata syukur artinya adalah berterima kasih, sedangkan kata nikmat artinya adalah pemberian, anugerah, enak, lezat. Mensyukuri nikmat Allah SWT, maksudnya berterima kasih kepada-Nya dengan cara mengingat atau menyebut nikmat dan mengagungkan-Nya. Terkait dengan hal ini, ada sebuah pandangan menarik juga diungkapkan Pak Wisnu berkaitan dengan laba, yaitu:

“...kalau manusia hidup mengejar materi tentu gak akan ada habisnya. Hidup jangan semata- mata hanya ditujukan untuk uang, laba kan berupa uang ya, tapi kalau bagi saya laba itu justru tidak ternilai, karena laba itu saya rasakan berupa nikmatnya berbagi ilmu yang bermanfaat, mendampingi anak-anak menjadi manusia yang keberadaannya itu menjadi berkah buat semua orang”.

Menurut pandangan Pak Wisnu, apabila kita mengejar materi maka tidak akan ada habisnya. Makna yang dapat dipetik dari pandangan Pak Wisnu ini adalah apabila seseorang mengejar materi maka tidak akan membuatnya menjadi puas, karena pada dasarnya manusia memiliki hawa nafsu. Jika seseorang hanya menuruti nafsunya terhadap materi maka tidak akan ada habisnya. Dalam hal ini, sangat dibutuhkan nilai-nilai religi di dalam diri setiap insan agar tidak mudah dikendalikan oleh hawa nafsunya.

Bagi Pak Wisnu, laba dirasakan dalam wujud kenikmatan berbagi ilmu yang bermanfaat bagi siswa-siswinya, dan mendampingi mereka agar menjadi manusia yang membawa keberkahan bagi orang lain. Pernyataan berikut ini merupakan prinsip yang dipegang teguh oleh Pak Wisnu dalam menjalani kegiatan di sekolah:

"Kalo saya mengajar, yang saya usahakan bukan hanya ilmu yang disampaikan tetapi juga kejujuran, keberanian, sikap saling menghargai, dan masih banyak lagi nilai-nilai teladan yang baik yang juga harus ditanamkan pada siswa. Saya berusaha memberikan yang terbaik untuk siswa bukan hanya sebagai pengajar tetapi pendidik".

Pak Wisnu mengemukakan prinsipnya bahwa dalam bekerja, prinsip yang dipegang teguh adalah bagaimana ia dapat memberikan yang terbaik bagi siswasiswinya, sehingga dari pengabdiannya selama ini diharapkan akan berbuah hasil yang lebih baik untuk peserta didik bukan hanya kebaikan dari ilmu tetapi juga nilai-nilai kehidupan yang menjadi teladan. Hal penting yang dipetik dari ungkapan tersebut dapat dipetik adalah pentingnya ketulusan dan keikhlasan dalam mengajar dan memberikan teladan yang baik bagi siswa.

Prinsip atau nilai-nilai kehidupan seperti ini makin jarang ditemui di jaman modern. Pengaruh paham kapitalisme yang semakin kuat dalam era kehidupan modern, telah melunturkan nilai-nilai luhur tentang ketulusan dan keikhlasan. Sehingga bagi masyarakat modern yang akidahnya telah tergerus oleh paham 
kapitalisme, menjadikan tradisi, adat istiadat, nilai-nilai religi dianggap suatu hal yang kuno dan ketinggalan jaman. Bagi mereka, segala sesuatu di dalam kehidupan diukur dengan nilai materi, sudah tidak terasa lagi nuansa kebersamaan, gotong royong dan tolong-menolong karena semua itu digantikan dengan seberapa banyak nilai yang nantinya akan didapat.

Pernyataan tentang makna laba yang disampaikan oleh Bu Nurul dan Pak Wisnu hampir sama dengan konsep laba dalam akuntansi syariah yang ditulis Safitri (2005). Di dalam akuntansi syariah dikenal adanya laba non material yang dibagi menjadi dua yaitu laba non material yang tidak bisa dirasa (pahala) dan laba non material yang bisa dirasakan keberadaanya diantaranya laba tenaga manusia (human income) dan laba sosial (sosial income). Kebahagiaan yang dirasakan oleh Bu Nurul dan Pak Wisnu merupakan wujud syukurnya kepada Allah, maka dari situlah nilai pahala akan didapat.

Hal tersebut berbeda dengan konsep laba yang dijelaskan Fisher dalam Subiyantoro dan Triyuwono (2004) bahwa laba sebagai serangkaian kejadian yang berhubungan dengan tiga hal kondisi yang berbeda, salah satunya yaitu laba kepuasan batin. Laba kepuasan batin merupakan laba yang muncul dari konsumsi sesungguhnya atas barang dan jasa yang menghasilkan kesenangan batin dan kepuasan atas keinginan. Laba kepuasan batin juga merupakan konsep psikologis yang tidak dapat diukur secara langsung, tetapi dapat diproksikan oleh laba sesungguhnya. Meskipun laba batin merupakan level laba yang paling fundamental, tetapi laba uang adalah laba yang paling sering diakui.

Menurut Fisher laba yang sesungguhnya adalah laba yang paling praktis yaitu uang. Namun begitu Fisher juga mengakui adanya pengertian lain dan mempunyai nilai yang fundamental dari laba sebagai aspek kekuatan psikologis, di mana laba tidak hanya diukur dari jumlah uang. Akan tetapi dari realitas sosial yang terjadi, Dalam hal ini, Fisher masih melihat bahwa uang sebagai nilai laba yang sesungguhnya. Pengertian sesungguhnya tidak sekedar berbentuk pengakuan realistis dalam realitas kehidupan sosial, tetapi pengertian sesungguhnya di sini memasuki wilayah intuisi yang berada dalam kesadaran manusia. Pandangan Fisher ini membalik tatanan sosial di mana faktor utama tidak lagi melihat atau memperhatikan nilai-nilai manusia dengan segala rasionalitas, psikologi dan nilainilainya. Akan tetapi faktor materi berupa uang adalah aspek mendasar dalam kehidupan manusia. Ini yang dianggap Barthes (1991) sebagai makna yang sesungguhnya.

\subsection{Semiotika Laba sebagai Kemaslahatan Masyarakat}

Ekonom klasik, seperti Adam Smith dan John Stuart Mill, berpendapat bahwa di satu sisi, ilmu ekonomi harus dapat menjelaskan tentang bagaimana manusia dan masyarakat mengorganisasikan kegiatannya untuk menciptakan keuntungan dan kesejahteraan banyak orang, namun disisi lain menurut mereka, ekonomi juga memiliki suatu fungsi untuk memberi alasan mendasar mengapa ekonomi perlu menfokuskan perhatiannya pada kesejahteraan bersama dan cara yang wajar untuk meningkatkan kekayaan, kemakmuran, dan kesejahteraan bersama tersebut. Ekonomi memiliki tugas untuk memberi prinsip yang rasional bagi bisnis sebagai kegiatan ekonomi, sehingga kegiatan ekonomi tersebut tidak hanya mengarahkan diri pada kebutuhan hidup manusia perorangan dan berjangka pendek saja, tetapi juga memberi surplus bagi kesejahteraan banyak orang. 
Aspek manusia menjadi sangat penting dalam konsep akuntansi mengingat manusia merupakan pihak pembuat sekaligus pelaksana dari konsep akuntansi. Tanpa adanya manusia, akuntansi tidaklah mungkin bisa dipikirkan, dilaksanakan, dan dikembangkan. Manusia juga merupakan faktor utama dalam penentuan arah berkembangnya akuntansi. Dengan melihat pentingnya aspek manusia, maka sudah selayaknya akuntansi tidak hanya dipandang dalam nilai materi tetapi juga harus mempertimbangkan unsur-unsur kehidupan yang lebih memandang manusia sebagai manusia, bukan sebagai sesuatu yang dapat dinilai dalam satuan moneter. Hal ini karena manusia memiliki sifat-sifat humanisme, seperti tulus, jujur, maupun ikhlas yang semuanya tidak dapat dinilai dalam bentuk uang.

Kekuatan dari rasa ikhlas untuk memberi yang terbaik bagi sesama saudaranya dalam bentuk materi maupun non-materi atau dalam bahasa Inggris disebut the power of giving juga dapat memberi nilai yang luar biasa untuk membangun suatu konsep dan nilai dari laba yang tangguh dalam jangka panjang. Hal tersebut dikarenakan laba yang merupakan sebuah kesempatan untuk lebih banyak memberikan manfaat kebaikan dan kepuasan bagi orang lain. Dengan demikian, laba yang berorientasi demikian akan memberikan orang lain mengenai apa yang menjadi manfaat dan kebaikan, bukan berpikir apa yang akan diperoleh dari orang lain.

Bagi mereka yang memandang laba dengan hati sebagai sebuah bentuk dari memberikan pelayanan pada dirinya, akan senantiasa menganggap laba yang dihasilkannya sebagai sebuah cerminan dari kontribusi yang wajib memiliki manfaat bagi orang lain. Hal tersebut dikarenakan makna laba tidak hanya berorientasi pada keuntungan yang realistis dalam satuan terukur demi kepentingan pribadi semata, namun juga mempertimbangkan kontribusi dan manfaat yang diberikan kepada orang lain. Dengan kata lain, nilai dari besaran laba akan tergambar bukan hanya dari nominal banyaknya keuntungan materi yang berhasil dibukukan, melainkan juga terkait seberapa besar manfaat kebaikan

yang diberikan kepada orang lain dari proses mendapatkan atau membentuk laba tersebut.

Bentuk nilai materi pada konsep laba akuntansi konvensional sebatas memperhitungkan nilai dalam satuan terukur, yaitu uang. Sedangkan bentuk nilai non-materi terlihat dari konsep laba akuntansi yang tidak hanya memperhitungkan nilai dalam satuan terukur, namun juga memperhitungkan nilai dalam satuan tidak terukur, yaitu mental yang dapat termanifestasi dalam bentuk rasa bangga karena turut membangun ekonomi masyarakat.

Bagi $\mathrm{Bu}$ Yana kemaslahatan masyarakat adalah bentuk dari laba yang dirasakan dengan cara berbeda, tidak ternilai secara materi. Dengan membantu membangun perekonomian masyarakat bukan hanya menjadi kepuasan batin buat dirinya sendiri, tetapi juga sebagai persembahan untuk masyarakat. Berikut yang dituturkan Bu Yana:

"kalau usaha/berbisnis seperti ini pasti punya persentase laba yang diharapkan...tapi bagi saya laba tidak hanya itu, ada laba yang sebenarnya sangat bernilai atau mungkin bahkan tak ternilai ya..yaitu membantu membangun perekonomian warga sekitar sini..akhirnya semua bisa usaha..tidak harus lari ke pabrik-pabrik ya..apalagi ibu-ibu yang sudah paruhbaya." 
Jika laba adalah sebuah persembahan untuk masyarakat, maka hal ini menggugurkan rumus pendapatan dikurangi beban, karena kebanggaan dan kebahagiaan yang ia peroleh berbeda dan seutuhnya diberikan pada desanya. Hal ini menggugurkan matching concept dan agency theory yang akrab dalam bidang akuntansi. Rasa bahagia atas kemaslahatan masyarakat sebagai bagian dari laba non-materi pada dasarnya merupakan cerminan dari mental yang memiliki nilai yang jauh lebih berharga dari materi (uang).

Pernyataan tersebut berbanding terbalik dengan kondisi masyarakat modern. Dalam masyarakat modern, uang (materi) menjadi pusat perhatian utama dalam melakukan usaha. Uang merupakan tujuan awal dan akhir dari suatu usaha yang dilakukan manusia. Dengan sejumlah uang yang ditanamkan dalam satu unit usaha atau instrumen investasi tertentu, manusia modern selalu mengharapkan jumlah yang ditanamkan tersebut akan terus bertambah. Pola berpikir demikian sangatlah wajar, mengingingat titik kebahagian dalam paradigma manusia modern yang menempatkan uang sebagai titik tertinggi dari pencapaian kebahagian mereka.

Selain bahagia atas apa yang dipersembahkan untuk masyarakat, $\mathrm{Bu}$ Yana juga puas dengan kepercayaan pelanggan. Bagi Bu Yana kepercayaan pelanggan tersebut merupakan penghasilan. Meskipun tidak selalu mendapat pujian atas produknya tetapi $\mathrm{Bu}$ Yana tetap semangat untuk terus memberikan yang terbaik untuk pelanggannya. Bu Yana mempertegas dengan menyatakan bahwa:

"penghasilan itu ya tidak sekedar berupa uang, tetapi yang lebih berharga adalah kepercayaan pelanggan. Mereka mempercayai kami untuk menyediakan kue dalam acaranya, mereka kembali lagi kesini menjadi pelanggan tetap itu kebanggaan tersendiri bagi kami."

$\mathrm{Bu}$ Yana langsung menambahi penjelasannya terkait beban. Berikut penjelasan $\mathrm{Bu}$ Yana:

"gak gampang memang awalnya mempromosikan produk ini. Harus ekstra tenaganya. Gak ada kata lelah. Karena bagi saya beban untuk mengurangi pengangguran itu lebih besar tak terhitung dalam bentuk uang."

Bagi $\mathrm{Bu}$ Yana beban adalah mengurangi jumlah pengangguran. Dengan demikian pertumbuhan perekonomian warga bisa jadi suatu persembahan karena bagi $\mathrm{Bu}$ Yana banyaknya pengangguran bukan hanya sebagi beban tetapi juga tanggungjawab pada daerahnya (bukan untuk dirinya sendiri namun untuk seluruh masyarakat yang ada di daerahnya) sehingga yang ia bawa dalam bentuk kepercayaan pelanggan bukan saja sebagai penghasilan, bukan hanya kepuasan diri, namun lebih dari itu kepercayaan pelanggan adalah sebuah kebahagiaan.

Kebahagiaan yang dirasakan $\mathrm{Bu}$ Yana atas pertumbuhan perekonomian masyarakat di daerahnya juga dirasakan oleh pengusaha UMKM lain yaitu $\mathrm{H}$. Fakih. Bagi H. Fakih seorang pengusaha selain memiliki menejemen yang bagus, ia juga harus memiliki loyalitas terhadap wilayahnya. H. Fakih mempertegas bahwa:

"pengusaha itu harus loyal pada daerahnya, karena dengan sikap loyal tersebut akan memunculkan cinta pada daerahnya, memompa semangat untuk berjuang menumbuhkan perekonomian daerah." 
H. Fakih memberikan penjelasan yang menunjukkan adanya rasa yang tak ternilai dalam satuan materi yaitu rasa cinta terhadap daerah. Banyak pandangan perusahaan modern yang menempatkan materi sebagai pusat dari dasar dan tujuan keberadaan manusia telah menciptakan satu bentuk realitas yang "kebablasan" dalam membaca makna dari loyalitas itu sendiri. Pemberian materi dengan mengalokasikan beban-beban tertentu, semisal pemberian bonus dan tunjangan dalam penghitungan laba-rugi, bagi banyak perusahaan modern dianggap sudah cukup untuk membeli rasa persaudaraan dan loyalitas dari setiap individu di dalam lingkungan perusahaan. Hal-hal seperti inilah yang kemudian membawa petaka bagi banyak perusahaan modern yang menjadikan materi sebagai pembentuk utama dari loyalitas. Timbulnya rasa persaudaraan dan loyalitas yang tulus dan ikhlas yang bersumber dari dalam hati seorang manusia dalam wujud solidaritas seakan mati ketika ia harus berhadapan dengan materi.

Materi menjadi aspek utama dalam membangun rasa persaudaraan dan rasa memiliki perusahaan (loyalitas). Sehingga menjadi tidak mengherankan jika banyak karyawan dalam perusahaan modern memiliki kecenderungan berpindah kerja dengan mudah menuju perusahaan lain, ketika mereka mendapat tawaran kebahagiaan materi yang lebih besar. Pandangan ini berbanding terbalik dengan apa yang dijelaskan oleh $\mathrm{H}$. Fakih. Beliau menjelaskan bahwa:

"loyalitas itu sendiri muncul karena adanya support, motivasi dari semua pihak, baik itu karyawan, masyarakat, teman, keluarga, pelanggan, supplier. Dan tak kalah pentingnya adalah do'a mereka yang selalu menemani kita."

Loyalitas yang muncul disini bukan dari seberapa besar uang yang dihasilkan. Tetapi loyalitas yang berkaitan dengan ikatan kejiwaan, rasa cinta antara pengusaha dan masyarakat sekitar. Mereka memahami bahwa jika mereka menampilkan kemampuan terbaik dari seluruh potensi yang mereka miliki, maka daerah dan masyarakat yang dicintainya akan bangga dan karyawan juga akan membalas dengan memberikan loyalitas serta ikut menjaga usaha tersebut. Laba dalam bingkai ini merupakan cerminan hubungan kejiwaan yang terbangun antara pengusaha dan masyarakat untuk memberikan yang terbaik dari dirinya kepada daerahnya guna mencapai tingkat kepuasan tertentu yang berasal dari hatinya.

Sayangnya masih banyak orang yang memandang sempit arti loyalitas. Hal ini telah membuat arti dari nilai persaudaraan seakan mati ketika nilai dari keuntungan materi dijadikan dasar pengukurannya. Dalam kaitannya dengan hal ini misalnya, konsumen atau pelanggan hanya dipandang dari nilai konsumsinya yang akan mempengaruhi pendapatan dalam laporan laba-rugi perusahaan. Kemudian karyawan sebagai bagian dari internal lingkungan perusahaan hanya dipandang dari nilai produktivitasnya, yang akan mempengaruhi jumlah barang maupun jasa yang dapat dihasilkan dan dijual perusahaan.

Memandang nilai persaudaraan lebih berharga dibandingkan keuntungan materi akan menjadikan perusahaan untuk semakin mampu memandang manusia sesuai kemampuan dan kapasitasnya atau dalam bahasa lain disebut dengan istilah memanusiakan manusia. Dalam proses mendapatkan laba tersebut, kesadaran mengenai konsep laba yang bukan sekedar berhubungan dengan alat-alat, komputer, mesin-mesin maupun perlengkapan kerja lainnya, namun juga berhubungan dengan 
manusia yang menjadi bagian terpenting dalam membentuk laba. Setiap keberhasilan dalam usaha selalu berhubungan dengan orang lain dan mendapatkan dukungan dari orang lain. Dalam membina hubungan dengan orang lain tersebut, apakah dengan karyawan, supplier, konsumen, maupun pihak lainnya, sebaiknya perusahaan senantiasa meletakkan dalam nilai-nilai yang melebihi keuntungan materi. Kemudian dalam memandang peranan manusia dalam konteks nilai persaudaraan tersebut, ia hendaknya bukan hanya dipandang sebagai bagian pelengkap untuk meraih besaran nilai laba, melainkan sebaiknya ia (manusia) diletakan secara utuh dalam bingkai nilai-nilai persaudaraan.

Dari penyataan $\mathrm{Bu}$ Yana dan $\mathrm{H}$. Fakih, kemaslahatan masyarakat bukan hanya sebagai laba tetapi justru sesuatu yang ingin dipersembahkan untuk masyarakat. Pengangguran yang menjadi beban justru adalah penyemangat mereka untuk memberikan yang terbaik untuk masyarakat dan penghasilan yang berupa kepercayaan masyarakat justru menjadi kepuasan batin.

Kondisi tersebut berbeda dengan rasionalitas ekonomi dalam manusia modern yang mana tidak lagi melihat pengetahuan manusia sebagai sebuah ungkapan keunggulan manusia sebagai makhluk yang berakal budi dan berakhlak mulia, melainkan menjadikan rasionalitas sebagai sarana untuk mencapai tujuan tertentu, telah menjadikan laba disini terbatas sebagai suatu bentuk yang akan kita peroleh dari suatu usaha untuk kepentingan pribadi dan bukan lagi sebagai suatu bentuk yang akan membawa kita menuju pemenuhan kepentingan bersama. Dengan demikian laba dimaknai sebatas sebuah senjata untuk mendapatkan tujuan yang kita inginkan terlepas dari bagaimana dan tujuan apa yang hendak ingin kita tuju, serta sarana apa yang hendak ingin kita gunakan. Pandangan ini tentunya memiliki pemahaman yang keliru jika kita mendasarkan nilai-nilai kehidupan yang lebih humanis sebagai salah satu komponen pembentuk laba.

Nilai-nilai kehidupan humanis yang mencoba untuk memberikan satu bentuk arahan nilai non- materi, diharapkan dapat memberikan suatu gambaran dan bentuk penyeimbangan yang baru dan jelas dari konsep laba akuntansi yang selama ini hanya mendasarkan dirinya pada bingkai materi. Hal tersebut, walau tidak sama persis namun telah dipaparkan terlebih dahulu oleh Zohar dan Marshall dalam bukunya Spiritual Capital (2004). Dalam konteks Spiritual Capital tersebut, mereka menjelaskan mengenai konsep modal spiritual yang dapat didefinisikan sebagai suatu bentuk kekayaan yang tidak hanya bersifat materi, namun dapat menghasilkan keuntungan yang dapat diambil dari dan ditambahkan pada kekayaan jiwa manusia dan pada kesejahteraan umat manusia secara umum (Zohar dan Marshall, 2004:78). Hal tersebut juga didukung dua pendapat dari Konusuke Matsushita dan Russel Ackhoff yang menyatakan "life isn't only for bread" dan "profit is a means, not an end". Dengan demikian pada hakikatnya disini, hidup bukan hanya bersumber dari sepotong roti (materi), namun juga bersumber dari nilai-nilai non-materi. Keuntungan (materi) sesungguhnya bukanlah tujuan utama, melainkan merupakan sebuah sarana untuk memberikan manfaat lebih banyak bagi orang lain. 


\section{KESIMPULAN}

Kesimpulan dari kajian ini menunjukkan bahwa laba memiliki makna denotasi dan konotasi. Laba tidak hanya mengandung unsur materialisme, tidak hanya sebagai bentuk kapitalisme, naum laba juga mengandung unsur-unsur humanisme. Realitas para akuntan menghasilkan persepsi bahwa laba adalah hasil penandingan (matching) antara penghasilan dan beban. Berbeda dengan kondisi tersebut, realitas non akuntan justru lebih banyak menunjukkan aspek humanisme. Persepsi tersebut semuanya memiliki kebenaran masing-masing. Hal ini disebabkan realitas yang diacu para informan juga berbeda. Dengan demikian kita mengetahui bahwa makna dari "teks" laba tidak stabil.

\section{DAFTAR PUSTAKA}

Accounting Terminology Bulletin No. 1, "Review and Resume" (New York: AICPA, 1953), ch. 9C, para. 5.

Allen, Graham. 2003.Roland Barthes. New York: Routledge, 2003.

Aminuddin. 2015. Semantik Pengantar Studi Tentang Makna. Bandung: Sinar Baru Algensindo.

Azwar, M. (2014). Teori Simulakrum Jean Baudrillard dan upaya pustakawan mengidentifikasi informasi realitas. Jurnal Ilmu Perpustakaan \& Kearsipan Khizanah Al-Hikmah, Vol. 2 No. 1, hlm. 38-48.

Barthes, R. 1977. Image Music Text. London: Fontana Press. Barthes, R. 1991. Mythologies. New York: The Noonday Press.

Bazan, Ariane. 2013. On the Physiology of Jouissance: Interpreting the Mesolimbic Dopaminergic Reward Functions From A Psychoanalytic Perspective. Hypothesis And Theory Article.

Belkaoui, A.R. 1980. The Interprofessional Linguistic Communication of Accounting Concepts: An Experiment in Sociolinguistic. Journal of Accounting Research 18 (2) Autumn:362-374.

Belkaoui, A. 1989. Accounting and Language. Jurnal of accounting literature vol.8 (281-292)

Burrell, G. Dan G. Morgan. 1979. Sociological Paradigms and Organisational Analysis. Ashgate Publishing Company. USA.

Cassirer, Ernst. 1955. The Philosophy of Symbolic Forms. London: Oxford University Press.

Creswell, John W. 2014. Research Design Pendekatan Kualitatif, Kuantitatif, dan Mixed. Yogyakarta

: Pustaka Belajar

Cummings, Louise. 1999. Pragmatic, A Multidiciplinary Perspective. New York: Oxford University Press Inc.

Derrida, J. 1978. "Structure, Sign, and Play in the Discourse of the Human Science". Terjemahan dalam Bahasa Inggris (Allan Bass): 1-13. Ringkasan Esai. Bagian dari Writing and Difference (pp. 278-294). Montreal.

Dreyfus, H.L. 2005. Companion to Heidegger. Australia : Blackwell Publishing.

Fanani, Fajriannoor. 2013. Semiotika Strukturalisme Saussure. The Messenger, Vol. V, No.1. Friedman, Milton. 1982. Capitalism and Freedom. The University of Chicago Press, Ltd., London Harlan, Richard. 2006. Super Strukturalisme 
: Pengantar Komprehensif pada Semiotika, Strukturalisme, dan Postrukturalisme. Jakarta, Bandung : Jalasutra.

Ikatan Akuntan Indonesia. 2017. Standar Akuntansi Keuangan. Jakarta : Salemba Empat

Indriantoro, N. 1999. Aliran-Aliran Pemikiran Alternatif dalam Akuntansi. Jurnal Ekonomi dan Bisnis Indonesia, Vol. 14 No.03.

Irianto, Gugus. 2006. Dilema "Laba" dan Rerangka Teori Political Economy of Accounting (PEA), TEMA, Vol.7, No.2, hal 141-153

Iselin, E. R.. 1971. The Objectives of Accounting in an Accounting Theory Based on Deductive Methodology. St.Lucia. University of Queensland Press

Kamayanti, Ari. 2016. Metodologi Penelitian Kualitatif Akuntansi. Jakarta Selatan: Yayasan Rumah Peneleh Kovacs, Z. I. 2012. Accounting-Profession vs Science. Focus on Accounting; hal 426-436.

Kuhn, T.S. (2002): A tudományos forradalmak szerkezete (The Structure of Scientific Revolutions). Osiris, Budapest

Kutha Ratna, N. 2010. Teori, Metode, dan teknik Penelitian Sastra. Yogyakarta : Pustaka Pelajar.

Macintosh, N.B., T. Shearer, D.B. Thornton dan M. Welker. 2000. Accounting as Simulacrum and Hyperreality: Perspectives on Income and Capital. Accounting Organization and Society (25): 13-50.

Moleong, L.J.. 2004. Metodologi Penelitian Kualitatif. Bandung : PT.Remaja Rosda Karya Muhajir, N.H.. 2002. Metode Penelitian Kualitatif. Rake Sarasin : Yogyakarta

Mursy, Austina Luckyta. 2013. Jurnal Akuntansi Multiparadigma, Vol.4, No.2, hal $165-176$

Nadeem; et.al. (2011). Teacher's Competencies and Factors Affecting the Performance of Female Teachers in Bahawalpur (Southern Punjab) Pakistan. International Journal of Business and Social Science 2 (19), 218.

Olaleye, \& Oluremi, F. (2013). Improving Teacher Performance Competency Through Effective Human Resource Practices In Ekiti State Secondary Schools. Journal Of Business Economics, and Management Studies 1(11), 125.

Piliang, Y.A. 2003. Hipersemiotika: Tafsir Cultural Studies Atas Matinya Makna. Bandung: Jalasutra.

Piliang, Y.A. 2004a. Dunia Yang Dilipat: Tamasya Melampaui Batas-Batas Kebudayaan. Yogyakarta dan Bandung: Jalasutra.

Piliang, Y.A. 2004b. Posrealitas: Realitas Kebudayaan Dalam Era Posmetafisika. Yogyakarta dan Bandung: Jalasutra.

Rahmat, Muhhamad. 2010. Pengungkapan Public Cost and Benefit dalam Perspektif Nilai Mahabbah (Cinta).

Skripsi. Malang: Program Strata 1 Universitas Brawijaya.

Ramlan, M. 2005. Ilmu Bahasa Indonesia Sintaksis. Yogyakarta: CV.Karyono

Riduwan, Akhmad. 2012. Realitas Dalam Cermin retak: Laba Akuntansi Dalam Bingkai Penafsiran Praktisi Bisnis Non-Akuntan (Studi Hermeneutika-Kritis). Sinopsium Nasional Akuntansi XV

Riduwan, Akhmad. 2010. Semiotika Laba Akuntansi: Studi Kritikal-Posmodernis Derridean. Jurnal Akuntansi dan Keuangan Indonesia, Vol.7, No.1, hal 38-60

Roslender, Robin. 1992. Sociological Perspectives on Modern Accountancy. London and New York: Routledge Salim, A. 2006. Teori \& Paradigma Penelitian Sosial. 
Yogyakarta: Tiara Wacana.

Sari, Dian Purnama. 2010. Tafsir Hermeneutika Intensionalisme atas "Laba" Yayasan Pendidikan. Tesis Universitas Brawijaya: Malang.

Sari, Dian Purnama. 2010. Tafsir "Keuntungan" bagi Profesi Dokter dengan Pendekatan Hermeneutika Intensionalisme. Sinopsium Nasional Akuntansi XIII

Sarup, M. 2008. Panduan Pengantar Untuk Memahami Post-Strukturalisme dan Posmo-dernisme. Cetakan I. Yogyakarta: Jalasutra.

Saussure, F.D. 1959. Course In General Linguistics. New York: Philosophical Library.

Shukla, S. 2014. Teaching Competency, Professional Commitment and Job Satisfaction - A Study of Primary School Teachers. Journal of Research and Method in Education (4), 44-64.

Sitorus, J.H. E. 2015. Dekonstruksi Definisi Akuntansi Dalam Perspektif Pancasila. Jurnal Akuntansi Multiparadigma.

Sobur, A. 2001. Analisis Teks Media: Suatu Pengantar Untuk Analisis Wacana, Analisis Semiotik dan Analisis Framing. Bandung: PT Remaja Rosdakarya.

Subanar, Harimurti. 2001. Manajemen Usaha Kecil. BPFE, Yogyakarta

Suwardjono. 2005. Teori Akuntansi: Perekayasaan Pelaporan Keuangan. Edisi Ketiga. Cetakan Pertama. Yogyakarta: BPFE.

Triyuwono, Iwan. 2006. Perspektif, Metodologi dan teori Akuntansi Syariah. Radja Grafindo Persada: Jakarta. Wild, J.K. 2005. Analisis Laporan Keuangan. Jakarta: Salemba Empat

Woods, Peter. 2006. Succesful Writing for Qualitative Researchers. London and New York: Routledge Yule, George. 1996. Pragmatics. New York: Oxford University Press. 